\title{
Implementasi Algoritma K-means Clustring dalam Penetuan Siswa Kelas Unggulan
}

\author{
Ari Sulistiyawati ${ }^{1, *}$, Eko Supriyanto ${ }^{2}$ \\ ${ }^{1,2}$ Fakultas Teknik dan Ilmu Komputer, Sistem Informasi, Universitas Teknokrat Indonesia, Bandar Lampung, \\ Indonesia \\ Email: 1,* ari sulistiyawati@teknokrat.ac.id, ${ }^{2}$ esupriyanto367@gmail.com \\ ${ }^{*}$ Email Penulis Utama
}

\begin{abstract}
Abstrak-Tujuan penelitian ini adalah mengembangkan sistem informasi berbasis web untuk mengelola data penilaian yang terpusat dalam menyajikan laporan hasil belajar siswa dan pengelompokan siswa pada kelas unggulan dengan mengimplementasikan algoritma $K$-means Clustring. Penerapan algoritma K-Means dengan mempartisi data ke dalam data dalam bentuk satu atau lebih kelompok, dimana data yang memiliki reprensentative persamaan dalam satu kelompok dan data yang memiliki perbedaan kelompok yang lain. Pengelompokan data dalam satuan pendidikan dilakukan untuk memudahkan fasilitasi pendidikan siswa berdasarkan perbedaan kemampuannya dalam belajar dan mengikuti pembelajaran. Penelitian dilakukan dengan metode pengembangan sistem mengikuti alur Systems development life cycle (SDLC) dengan model sekuensial linier (sequential linear) atau alur hidup klasik (classic life cycle). Tahap penelitian meliputi Analisis, Desain, Pengodean dan Pengujian sistem. Sistem yang dikembangkan diimplementasikan pada salah satu sekolah di Lampung untuk mengelompokkan siswa pada kelas unggulan dengan jumlah anggota keseluruhan sebanyak 6 kelas VII dengan jumlah total 192 siswa pada tahun pelajaran 2020. Hasil Penelitian didapat aplikasi pengelolaan data penilaian yang terpusat dalam menyajikan laporan hasil belajar siswa menggunakan hasil nilai rapor kurikulum 2013. Penilaian tersebut menjadi dasar atribut yang digunakan dalam proses perhitungan untuk menetukan siswa kelas unggulan. Hasil klarifikasi Kelas unggulan di butuhkan suatu implementasi system informasi terbentuk 2 cluster setiap kelas. Setiap klasteriasi perputaran pada masing-masing kelas kemudian dihasilkan jumlah siswa masuk kelas unggulan sebanyak 96 dan siswa tidak masuk kelas unggulan sebanyak 96. Penerapan sistem informasi klastrisasi berbasis web dihasilkan informasi yang lebih fleksibel dapat diakses secara global pihak instansi. Pengujian black-box Testing lebih berfokus dengan pengujian fungsional menunjukkan perangkat lunak dapat berfungsi baik dalam mengelompokkan data. Pengujian penerimaan user terhadap pengembangan sistem informasi menggukan technologi Acceptance Model (TAM) menunjukkan aplikasi yang dibangun memberikan kemudahan dan tepat guna untuk diimplementasikan dalam mengelompokkan siswa kelas unggulan di sekolah. Dengan membangun atau implementasi ke dalam system informasi algoritma k-means clustering hasil klarifikasi klasterisasi sehingga efektif dan proses setiap iterasi perputaran jarak centroid, penetuan titik cluster dibantuk, dan lebih menghemat waktu melakukan klasterisasi kelas unggulan.
\end{abstract}

Kata Kunci: algoritma $K$-means Clustring, kelas unggulan, kelompok data

Abstract-The purpose of this research is to develop a web-based information system for grouping students in superior classes by implementing the K-means Clusting algorithm. The application of the K-Means algorithm by partitioning data into data in the form of one or more groups, where data has a representative equation in one group and data that has differences in another group. Data grouping in educational units is carried out to facilitate the facilitation of student education based on differences in their ability to learn and participate in learning. The research was conducted with a system development method following the Systems development life cycle (SDLC) with linear sequential models or classic life cycles. The research stage includes Analysis, Design, Coding and Testing of the system. The system developed was implemented one of the schools in Lampung in grouping students in the superior class with 6 class VII with a total number of 192 students in the academic year 2020. The results of the study obtained a centralized assessment data management application in presenting reports on student learning outcomes using the 2013 curriculum report. Value data has attributes that are used in the calculation process to determine the superior class students. The results of the clarification of the superior class requires an implementation of an information system to form 2 clusters per class. Each rotation classification in each class resulted in 96 students entering the superior class and 96 students not entering the superior class. The application of a web-based classification information system resulted in more flexible information accessible globally by agencies. Blackbox testing focuses more on functional testing showing the software can function well in classifying data. Testing user acceptance of the development of information systems using Acceptance Model (TAM) technology shows that the application built provides ease and efficiency to be implemented in grouping superior class students in schools. By building or implementing into the k-means clustering algorithm information system the results of the clustering classification are so effective and the process of each iteration of the centroid rotation distance, the determination of cluster points is assisted, and saves more time doing superior class clustering.

Keywords: K-means Clustring algorithm, featured class, data grouping 


\section{PENDAHULUAN}

Salah satu bentuk inovasi dalam bidang pendidikan, adalah mengembangkan aplikasi yang dapat dimanfaatkan baik dalam pembelajaran maupun administratif sekolah. Sebagai upaya meningkatkan mutu pendidikan melalui layanan pembelajaran adalah membentuk kelompok belajar siswa dalam kelas sesuai dengan kriteria siswa.

Penentuan masuk kelas unggulan sangatlah penting dimana informasi yang dihaslikan dapat dijadikan sebagai acuan bahan pertimbangan bagi pihak sekolah untuk melakukan langkah secara terstuktur untuk rangka meningkatkan kualitas dan standar mutu jenjang sekolah menegah pertama kelas unggulan. Langkah-langkah menentukan siswa masuk ke kelas unggulan di dapat hasil legger terdiri 2 aspek penilaian dikalkulasi sudah melewati cakupan tingkat akurasi nilai tertinggi dari standar batasan keriteria ketutansan minimum (KKM). Dari hasil identifikasi data nilai rapot kurikulum 2013, menujukan atribut penilaian beragam hasil. Secara garis besar memiliki persamaan nilai memiliki variasi kriteria jumlah yang cenderung setara antar individu siswa. Slain itu, penepatan kapasistas jumlah siswa kelas unggulan setiap tahun ajaran dapat berubah-ubah seiring dengan pengembangan sekolah dan jumlah penerimaan siswa. Pemecahan permasalahan pengelompokan siswa dengan data yang semakin banyak menjadi kurang efesien dan dibutuhkan pengelompokan siswa yang juga memiliki prestasi untuk masuk kelas unggulan telah ditetapkan. Pengelompokan siswa pada kelompok yang tepat akan mampu mengimprovisasi hasil pembelajaran menjadi lebih baik (Henry, 2013).

Metode yang digunakan untuk membagi rangkaian data menjadi beberapa group berdasarkan kesamaan-kesamaan yang telah ditentukan sebelumnya adalah bentuk Clustering atau klasifikasi (Widodo, 2013). Partisi data ke dalam data yang ada dalam bentuk satu atau lebih kelompok dapat dilakukan dengan menerapkan algoritma K-Means. Pemilihan metode K-Means dikarenakan metode ini harus menggunakan data fisik tidak abstrak dan bersifat jelas, hal ini sesuai dengan data yang akan digunakan pada permasalahan di dalam pengelompokan kelas unggulan disekolah dengan memanfaatkan nilai rapor siswa sebagai acuan datanya. Selain itu, metode ini bersifat fleksibel sebab pengguna dapat menentukan jumlah cluster yang akan dibuat.

Algoritma K-Means merupakan algoritma non hirarki yang berasal dari metode data clustering. Algoritma K-Means dimulai dengan pembentukan partisi klaster diawal kemudian secara iteraktif partisi claster ini diperbaiki hingga tidak terjadi perubahan yang signifikan pada partisi claster (Written, 2011). Menurut Eko Prasetyo (2012) mengatakan bahwa metode K-Means ini mempartisi data ke dalam kelompok sehingga data berkarakteristik sama dimasukan kedalam sat kelompok yang sama dan data yang berkarakteristik berbeda dikelompokkan kedalam kelompok yang lain. Data yang memiliki reprensentative persamaan nilai dalam satu kelompok dan data yang memiliki perbedaan kelompok yang lain sehingga memungkinkan pengelompokan data yang berbeda yang memiliki tingkat variasi kecil. Prinsip utama dari teknik ini adalah menyusun K buah partisi/pusat massa (centroid)/rata-rata (mean) dari sekumpulan data. Adapun tujuan dari pengelompokan data ini adalah untuk meminimalkan fungsi objektif yang diset dalam proses pengelompokan, yang pada umumnya berusaha meminimalkan variasi dalam suatu kelompok dan memaksimalkan variasi antar kelompok.

Langkah-langkah melakukan clustering dengan metode K-Means adalah sebagai berikut:

1. Tentukan nilai $\mathrm{k}$ sebagai jumlah klaster yang ingin dibentuk.

2. Inisialisasi $\mathrm{k}$ pusat cluster ini bisa dilakukan dengan berbagai cara, namun yang paling sering dilakukan adalah dengan cara random yang diambil dari data yang ada.

3. Menghitung jarak setiap data input terhadap masing - masing centroid menggunakan rumus jarak Euclidean (Euclidean Distance) hingga ditemukan jarak yang paling dekat dari setiap data dengan centroid. Berikut adalah persamaan Euclidian Distance :

$D e=\sqrt{\left(x_{i}-s_{i}\right)^{2}\left(y_{i}-t_{i}\right)^{2}}$

dimana :

De adalah Euclidean Distance

i adalah banyaknya objek,

$(\mathrm{x}, \mathrm{y})$ merupakan koordinat object dan

$(\mathrm{s}, \mathrm{t})$ merupakan koordinat centroid.

4. Mengklasifikasikan setiap data berdasarkan kedekatannya dengan centroid (jarak terkecil).

5. Memperbaharui nilai centroid. Nilai centroid baru di peroleh dari rata-rata cluster yang bersangkutan dengan menggunakan rumus:

$v_{i j}=\frac{1}{N_{i}} \sum_{k=0}^{N_{i}} X_{k j}$

dimana :

vij adalah centroid/ rata-rata cluster ke-i untuk variable ke-j

$\mathrm{Ni}$ adalah jumlah data yang menjadi anggota cluster ke-i

$\mathrm{i}, \mathrm{k}$ adalah indeks dari cluster

$\mathrm{j}$ adalah indeks dari variabel

xkj adalah nilai data ke-k yang ada di dalam cluster tersebut untuk variable ke-j 
6. Melakukan perulangan dari langkah 2 hingga 5, sampai anggota tiap cluster tidak ada yang berubah.

Beberapa penelitian terdahulu menerapkan metode K-Means Clustering pengelompokan data, diantaranya penelitian Teguh Wibowo (2018), yang bertujuan untuk mengklastering siswa kelas unggulan menggunakan metode clustering dengan algoritma k-means, serta pemilihan atribut sesuai dengan kebutuhan di SMP N 02 Tasikmadu sehingga dihasilkan Kelas unggulan yang diharapkan yaitu 3 kelas favorit meliputi siswa-siswa pilihan yang memiliki nilai rapor sesuai dengan standar nilai kemampuan siswa agar dapat meningkatkan proses belajar sesuai nilai bakat kemampuan siswa mencapai hasil optimal. Selanjutnya, Nofrida Rif’atul Himmah (2016) mengembangkan sistem yang lebih efektif dalam pengelompokan prestasi akademik siswa, salah satu cara mengelompokkan data yang efektif adalah dengan menggunakan teknik data mining klastering, sehingga dapat memudahkan pekerjaan bagi Wakil kepala sekolah bidang kurikulum mengetahui siswa yang mempunyai prestasi akademik baik, sedang dan kurang, yang bisa dijadikan acuan dalam membentuk kondisi kelas yang seimbang. Demikian juga penelitian Aniek Surya Kusuma dan Komang Sri Aryati (2019), dibuatkan sistem yang terintegrasi dengan data siswa dan nilai siswa berbasis database sehingga saat nilai dibutuhkan sewaktu-waktu membuat laporannya akan lebih efektif dan efisien serta membandingkan nilai siswa dengan batas minimal nilai untuk masuk ke kelas A di SMP Negeri 3 Ubud. Hal ini yang kemudian menjadi masukan untuk mengelola data penilaian yang terpusat dalam menyajikan laporan hasil belajar siswa dan mengimplementasikan Algoritma Kmeans dalam mengelompokkan kelas unggulan di SMP dengan studi kasus data siswa di SMPN 2 Jati Agung Kabupaten Lampung Selatan.

\section{METODE PENELITIAN}

\subsection{Metode Penelitian}

Metode penelitian ini menggunakan metode Systems development life cycle (SDLC) dengan model sekuensial linier (sequential linear) atau alur hidup klasik (classic life cycle) yang meliputi Analisis, Desain, Pengkodean dan Pengujian (Rosa dan Shalahuddin, 2014). Pada tahapan ini terdapat empat tahapan dapat pada gambar berikut :

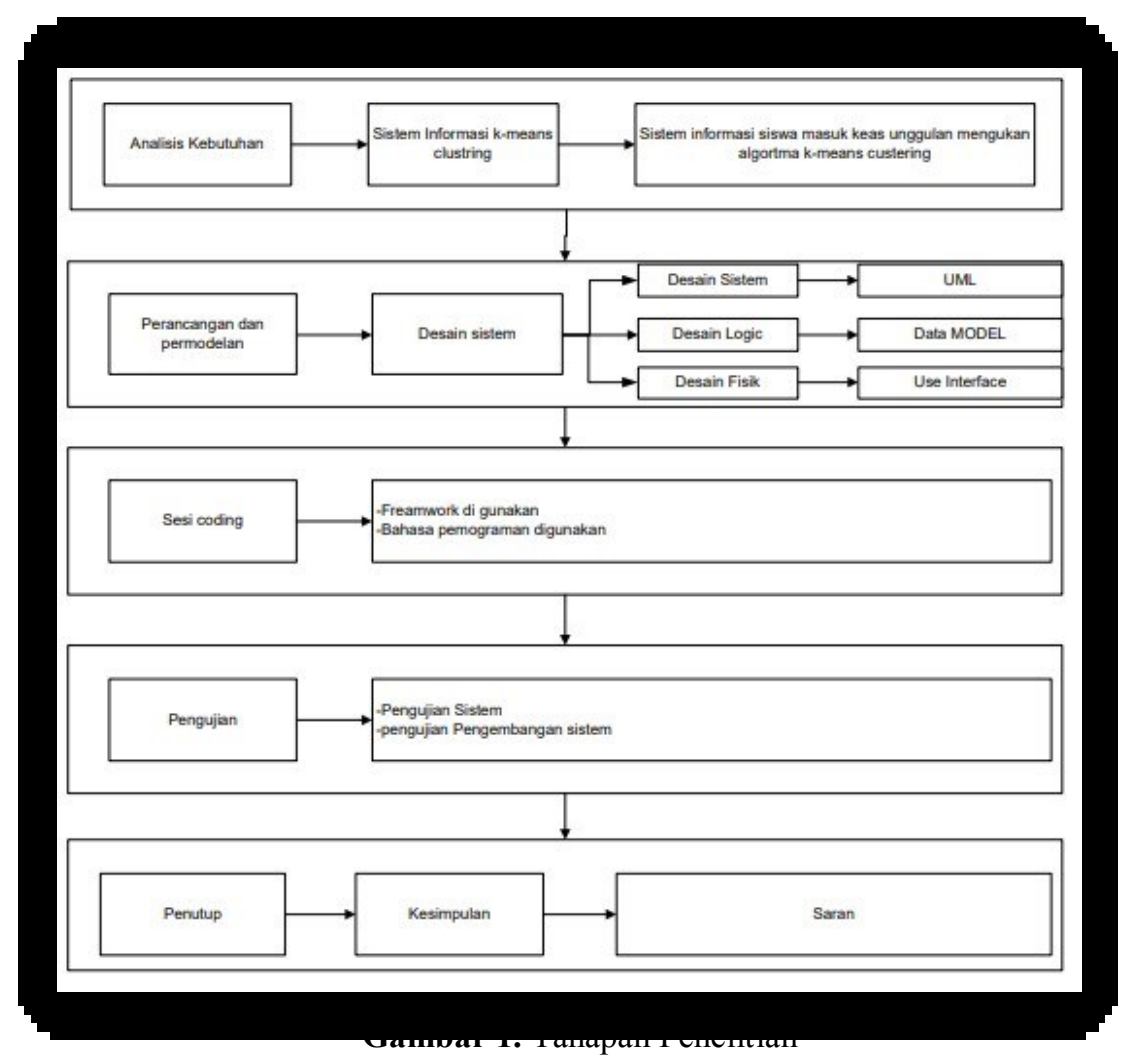

Penelitian ini meliputi tahap-tahap sebagai berikut:

\section{Analisis Kebutuhan}

Kerangka penelitian berawal dari identikikasi kebutuhan, identifikasi kebutuhan ini dilakukan dengan pengumpulan data berupa wawancara, dokumentasi dan tinjauan pustaka. Sebagai objek penellitian sebagai tempat studi kasus dilakukan di SMPN 2 Jati Agung Kabupaten Lampung Selatan yang 
menerapkan kelas unggulan dalam mengelompokkan kelas pembelajaran. Salah satu sekolah di Lampung ini mengelompokkan siswa pada kelas unggulan dari jumlah anggota keseluruhan sebanyak 6 kelas VII dengan jumlah total 192 siswa pada kenaikan kelas VIII di tahun pelajaran 2020. Tinjauan pustaka atau kajian literatur dilihat berdasarkan buku dan jurnal yang sesuai dengan penelitian yang diangkat. Setelah melakukan pengumpulan data selanjutnya mengidentifikasi masalah dan lingkup penelitian.

2. Perancangan Dan Permodelan

Perancangan sistem merupakan proses multi langkah yang fokus pada rancangan pembuatan perangkat lunak termasuk struktur data, arsitektur perangkat lunak, representasi antar muka, dan prosedur pengkodean. Tahap ini mentranslasi kebutuhan perangkat lunak dari tahap analisis kebutuhan yang merepresentasikan rancangan agar dapat diimplmentasikan menjadi program pada tahap selanjutnya. Perancangan sistem yang dihasilkan pada tahap ini didokumentasikan menggunakan pendekatan Object Oriented Programming (OOP) dengan Unified Modeling Language (UML) yaitu use case menggambarkan proses yang dilakukan oleh aktor, class diagram dan activity diagram. Implementasi $K$-Means Clustering mengikuti alur flowchat berikut ini.

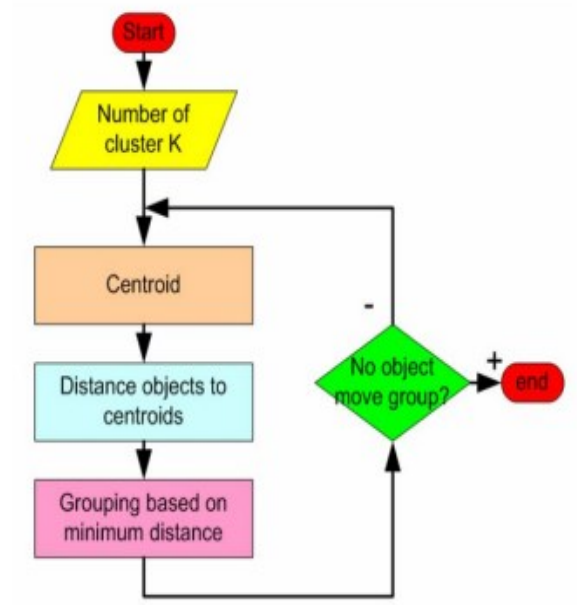

Gambar 2. Flowchart K-means Clustering

\section{Pengkodean / Sessi Coding}

Desain harus ditranslasikan ke dalam program perangkat lunak. Hasil dari tahap ini adalah program komputer sesuai dengan desain yang telah dibuat pada tahap desain :

a. Freamwork digunakan sebagai membangun suatu perangkat lunak di tetapkan menggukan Codeigniter dengan mengeimplemantasikan interface atau setruktur dari OOP codeigniter yang di dalam nya terdapat susuanan Freamwork sebagai berikut Model, View, Contoller (MVC). Memishkan bagian sintax ( kode ) melakuakn proses di perintahkan.

Terdapat 3 komponen sesuai version di gunkan dalam pengembangan aplikasi perangkat lunak dapat di jabarkan sebagai berikut ini :

1) View, berfokus ke bagian interface tampilan. Di setiap aplikasi berupa file berformat HTML fungsi ini menerima dan mengimplentasikan kepada user.

2) Model, berhubung dengan query data base.

3) Controller, merupakan class fungsi dapat mengontrol aktifitas dari View, dan Model. Fungsi ini sebagai perintah yang akan di jalan kan sesuai alokasi sintax di kembangkan atau di buat.

b. Scripting Langguange Pemograman PHP.

Merupakan Bahasa pemogramanan serign di guakan pengembangan aplikasi perangkat lunak. PHP merupakan kependekan Hypertext Preprocessor serign di sebut Tools Person Home Page. Memproses seluruh perintah berada pada sintax PHP di dalam aplikasi di bangun dan menapilkan output ke dalam browser.

\section{Pengujian Sistem}

Pengujian sistem dilakukan dengan pengujian black box dan Technology Acceptance Model (TAM). Pengujian black box dilakukan untuk menguji perangkat lunak dari segi spesifikasi fungsional tanpa menguji desain dan kode program. Menurut Rosa A.S. dan M. shalahuddin (2013), pengujian dimaksudkan untuk mengetahui apakah fungsi- fungsi masukan, dan keluaran dari perangkat lunak sesuai dengan spesifikasi yang dibutuhkan. Sedangkan Pengujian TAM merupakan salah satu model evaluasi kesuksesan sistem informasi dilihat dari penggunaan sistem. TAM yang dikenalkan oleh Davis pada tahun 1989 ini adalah teori sistem informasi yang membuat model tentang bagaimana 
pengguna mau menerima dan menggunakan teknologi. Model ini akan memberikan gambaran bahwa ada sejumlah faktor yang mempengaruhi keputusan pengguna dalam menggunakan sistem yang baru yakni kebermanfaatan dan kemudahan. Kebermanfaatan menunjukan keyakinan pengguna pada konstribusi sistem informasi terhadap kinerja pengguna sistem informasi dan kemudahan menunjukan tingkat dimana pengguna meyakini bahwa penggunaan sistem informasi adalah mudah dan tidak memerlukan usaha keras. Konsep ini mencakup kejelasan tujuan pengguna sistem informasi dan kemudahan pengguna sistem untuk tujuan sesuai dengan keinginan pengguna sehingga apabila sistem informasi mudah digunakan, maka pengguna akan cenderung untuk menggunakan sistem informasi tersebut.

\section{HASIL DAN PEMBAHASAN}

\subsection{Hasil Penelitian}

Mengacu pada tugas - tugas sistem maupun tugas actor sekaligus berperan mengelola system natinya dapat lampirkan sebagai berikut:

1. Guru masing-masing mata pelajaran akan menyerahkan hasil nilai lagger siswa ke wali kelas perserta didik masing-masing sudah di rekaputasi microsoft excel selanjutnya untuk di Import dalam system informasi, maupaun form input telah di sediakan ke system.

2. Admin melakukan pengeceakan nilai lagger sudah kalkulasikan menjadikan hasil nilai rapot, penerapan metode clustering algorithma k-means sistem akan mengolah nilai siswa menjadikan objeck fungsi atribut mengelola objeck dalam sekala besar dan mengelompokkan sesuai dengan nilai terdekat dengan titik pusat cluster. Menghitung semua jarak data ke setiap titik pusat cluster dengan mengimplementasikan sintax program diterapkan sistem informasi menggukan teori rumus jarak Euclidean Distince.

Hasil Data di ambil dari SMP N 2 Jati Agung Lampung Selatan hasil nilai rapot kurikulum k13 masingmasing data memiliki atribut digunakan dalam proses perhitungan untuk menetukan siswa kelas unggulan. Pada data siswa atribut di seleksi dan dipilih beberapa mata pelajaran sesuai kriteria yang ditentukan berdasarkan kebijakan sekolah untuk digunakan dalam proses mining. Berikut seleksi atribut seperti yang ada pada tabel berikut ini.

Tabel 1. Seleksi Atribut

\begin{tabular}{|l|c|}
\hline \multicolumn{1}{|c|}{ Atribut } & $\begin{array}{c}\text { Digunakan } \\
\text { v (ya) / x (tidak) }\end{array}$ \\
\hline Pendidikan Agama \& Budi Perkerti & $\mathrm{V}$ \\
\hline PPKN & $\mathrm{X}$ \\
\hline Bahasa Indonesia & $\mathrm{V}$ \\
\hline MTK & $\mathrm{V}$ \\
\hline IPA & $\mathrm{V}$ \\
\hline IPS & $\mathrm{X}$ \\
\hline BAHASA INGGRIS & $\mathrm{V}$ \\
\hline SENI BUDAYA & $\mathrm{X}$ \\
\hline PJOK & $\mathrm{X}$ \\
\hline PRAKARYA & $\mathrm{X}$ \\
\hline Jumlah nilai rapot & $\mathrm{X}$ \\
\hline Nilai rata-rata & $\mathrm{V}$ \\
\hline
\end{tabular}

Dari jumlah anggota keseluruhan sebanyak 6 kelas dengan jumlah total 191 siswa, penentuan kelas unggulan dengan algoritma k-means clustring kelas VII nilai rapot semester 2 disesuaikan dengan parameter nilai atribut keseluruhan sebagai penerapan titik objek. Dalam raport siswa K13 pertama harus melalui tahapan kalkulasi terdiri dari 2 aspek legger pengetahuan dan ketrampilan mencari hasil nilai rata-rata raport, diasumsikan sebanyak 32 siswa kelas sebagai acuan penetuan objeck dengan terapkan metode k-Means di harapkan mempermudah pengelompokan siswa masuk kelas unggulan. 
Tabel 2. Data Nilai Siswa Tentukan Sebagai Objek

\begin{tabular}{|c|c|c|c|c|c|c|}
\hline $\begin{array}{l}\text { No. Absen } \\
\text { Siswa }\end{array}$ & $\begin{array}{l}\text { Agama dan } \\
\text { Budi pekerti }\end{array}$ & $\begin{array}{c}\text { Bahasa } \\
\text { Indonesia }\end{array}$ & Matematika & IPA & Bahasa Inggris & Nilai Rata-rata \\
\hline 1 & 78 & 88 & 79 & 82 & 83 & 82,6 \\
\hline 2 & 80 & 83 & 87 & 80 & 86 & 83,75 \\
\hline 3 & 80 & 84 & 81 & 82 & 78 & 81,7 \\
\hline 4 & 78 & 88 & 81 & 82 & 80 & 82,2 \\
\hline 5 & 78 & 89 & 83 & 80 & 79 & 81,15 \\
\hline 6 & 78 & 88 & 84 & 84 & 82 & 83 \\
\hline 7 & 80 & 84 & 80 & 82 & 83 & 82,05 \\
\hline 8 & 79 & 89 & 80 & 83 & 83 & 82,15 \\
\hline 9 & 78 & 88 & 80 & 80 & 74 & 80,95 \\
\hline 10 & 80 & 76 & 81 & 84 & 80 & 81,9 \\
\hline 11 & 80 & 89 & 85 & 84 & 81 & 82,65 \\
\hline 12 & 78 & 88 & 79 & 83 & 77 & 81,65 \\
\hline 13 & 78 & 85 & 86 & 85 & 82 & 82,4 \\
\hline 14 & 80 & 85 & 80 & 85 & 80 & 82,6 \\
\hline 15 & 80 & 89 & 81 & 86 & 84 & 83,45 \\
\hline 16 & 78 & 83 & 81 & 83 & 81 & 81,65 \\
\hline 17 & 79 & 79 & 84 & 79 & 75 & 79,9 \\
\hline 18 & 79 & 83 & 84 & 80 & 80 & 81,5 \\
\hline 19 & 78 & 79 & 77 & 80 & 80 & 80,5 \\
\hline 20 & 82 & 89 & 80 & 82 & 82 & 83 \\
\hline 21 & 79 & 85 & 82 & 83 & 84 & 81,95 \\
\hline 22 & 78 & 80 & 82 & 81 & 81 & 81,3 \\
\hline 23 & 79 & 89 & 82 & 82 & 79 & 81,7 \\
\hline 24 & 79 & 85 & 81 & 80 & 79 & 81,7 \\
\hline 25 & 78 & 83 & 80 & 82 & 80 & 81,5 \\
\hline 26 & 78 & 88 & 84 & 81 & 81 & 81,8 \\
\hline 27 & 79 & 89 & 81 & 83 & 79 & 82 \\
\hline 28 & 78 & 83 & 85 & 82 & 81 & 82,1 \\
\hline 29 & 78 & 88 & 80 & 80 & 80 & 80,35 \\
\hline 30 & 81 & 84 & 86 & 84 & 79 & 82,8 \\
\hline 31 & 79 & 89 & 86 & 82 & 80 & 82,6 \\
\hline 32 & 78 & 89 & 80 & 81 & 79 & 81,55 \\
\hline
\end{tabular}

Proses Algorthma K-means Clustering dilakukan melalui pengelompokan data dengan tahapan sebagai berikut:

1. Tentukan jumlah cluster yang ingin dibentuk cluster.

2. Menentukan centroid (titik pusat cluster) awal pembangkitan bilangan secara Max. Dengan $\mathrm{C} 0=$ Banyak objeck nilai dan $\mathrm{C} 1=$ Sedikit objeck nilai

3. Menghitung jarak setiap objeck ke titik pusat centroid dengan menggunakan rumus jarak Euclidean Distance

4. Menghitung jarak tiap titik objeck dengan (data nilai siswa) menghasilkan nilai rata-rata (mean) centroid 1 :

$\mathrm{D} 12=(82-78)^{2}+(84-88)^{2}+(89-79)^{2}+(80-82)^{2}+(85-83)^{2}+(83-82,6)^{2}=8.2735464$.

5. Menghitung jarak tiap titik objeck dengan (data nilai siswa) menghasilkan nilai rata-rata (mean) centroid 2:

$\mathrm{D} 24=(77-78)^{2}+(76-88)^{2}+(77-79)^{2}+(77-82)^{2}+(74-83)^{2}+(79-82,6)^{2}=16.3805524$.

6. Mengelompokkan setiap data berdasarkan jarak terdekat antara data dengan centroid.

7. Kembali ke tahap ke-2, lakukan perulangan hingga nilai centroid yang dihasilkan tetap dan anggota cluster tidak berpindah ke cluster lain. 


\subsection{Perancangan Sistem}

Perancangan use case diagram mendeskripsikan sebuah interaksi antara satu atau lebih actor dengan sistem informasi yang akan dibuat serta menggambarkan fungsionalitas yang diterapkan dari sebuah sistem. Use case digunakan untuk mengetahui fungsi apa saja yang ada didalam sebuah sistem informasi dan siapa saja yang berhak menggunakan fungsi-fungsi. Berikut mendeskripsikan alur kerja actor dalam system di terapakn sebagai berikut.

Tabel 3. Definisi Alur Use Case Diagram Admin

\begin{tabular}{|c|l|l|}
\hline No & \multicolumn{1}{|c|}{ Actor } & \multicolumn{1}{|c|}{ Deskripsi } \\
\hline 1 & Admin & $\begin{array}{l}\text { Memiliki wewenang sebagai pengelola } \\
\text { system admin dan memiliki akses login, mengelola data } \\
\text { tahunajaran, mengelola data master kelas, mengelola data nilai } \\
\text { siswa, mengelola import data nilai legger, mengelola data user } \\
\text { admin, mengelola data wali kelas, mengelola penetuan form input } \\
\text { centroid cluster awal, mengelola data k-means pengelompokan } \\
\text { atau kumpulan dari nilai rat-rata- mean jumlah item anggota } \\
\text { setiap iterasi. }\end{array}$ \\
\hline 2 & Wali kelas & $\begin{array}{l}\text { Memiliki akses system, mengeloal data } \\
\text { form input nilai legger, mengelola import nilai legger, } \\
\text { mengelola data wali kelas. }\end{array}$ \\
\hline
\end{tabular}

Penggambaran Use Case Diagram yang terdiri dari 2 aktor untuk proses pengelompokan siswa masuk kelas unggulan digambarkan sebagai berikut berikut.

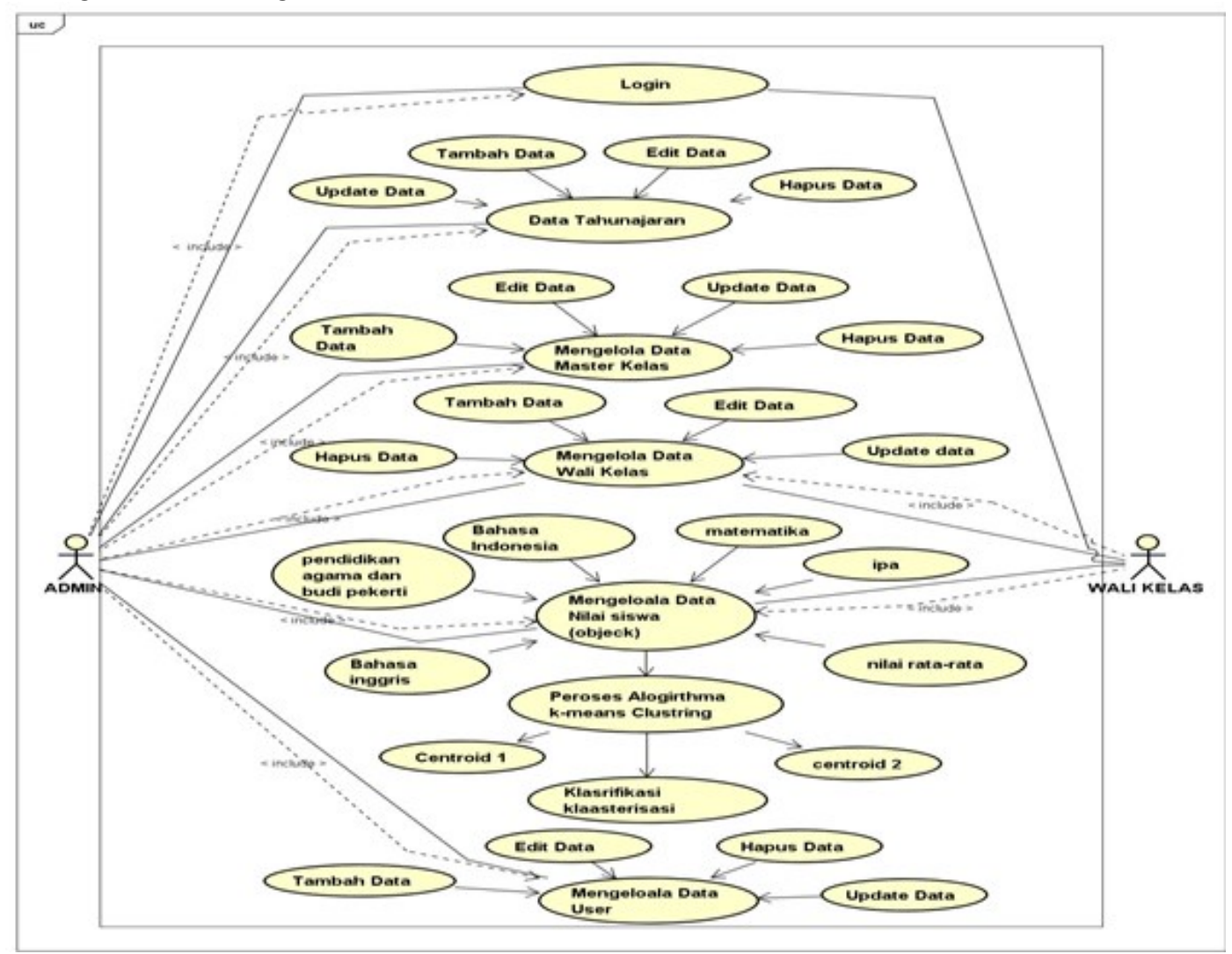

Gambar 2. Use Case Diagram

\subsection{Implementasi}

Menggunakan framewrok Codeigniter version $2.0 \mathrm{php}$ version 5, dimana SQL Server sebagai database. Algoritma K-Means sistem akan mengolah nilai siswa dan mengelompokkan sesuai dengan nilai terdekat dengan titik pusat cluster sehingga prediksi klasterisasi mendapatkan pencapaian yang akurat. 
Halaman utama Website klasterisasi dapat di akses secara global wilayah instansi dalam studi kasus penelitian melalui Interface Index Home .

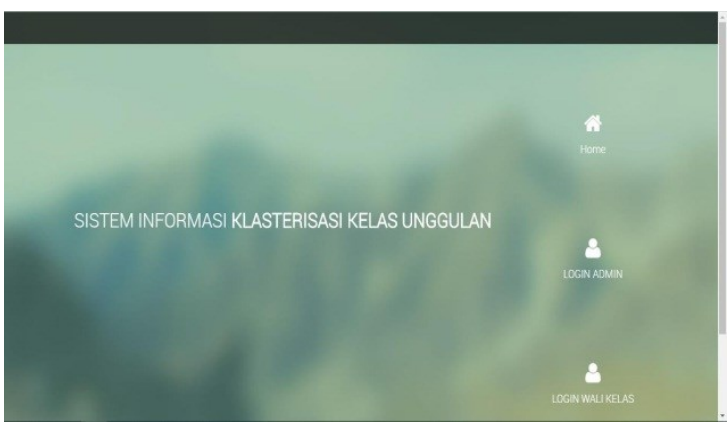

Gambar 3. Halaman Utama Sistem Informasi Klasterisasi Kelas Unggulan

Untuk membedakan, data pada tiap tahun pelajaran maka aplikasi diawali dengan interface form input data tahun ajaran

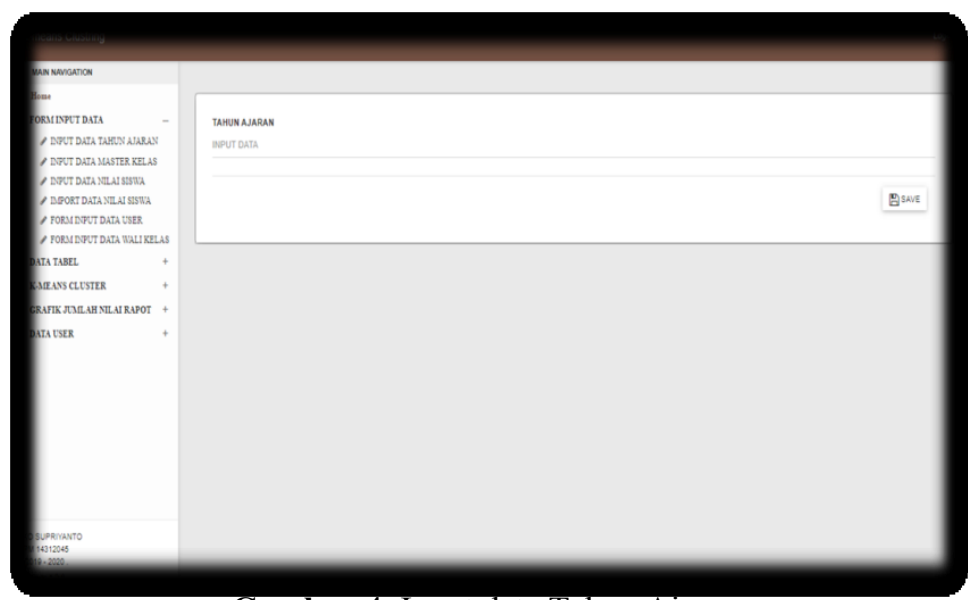

Gambar 4. Input data Tahun Ajaran

Selanjutnya, pengisian data nilai melalui form input data nilai siswa berdasarkan nilai rapor pada data legger.

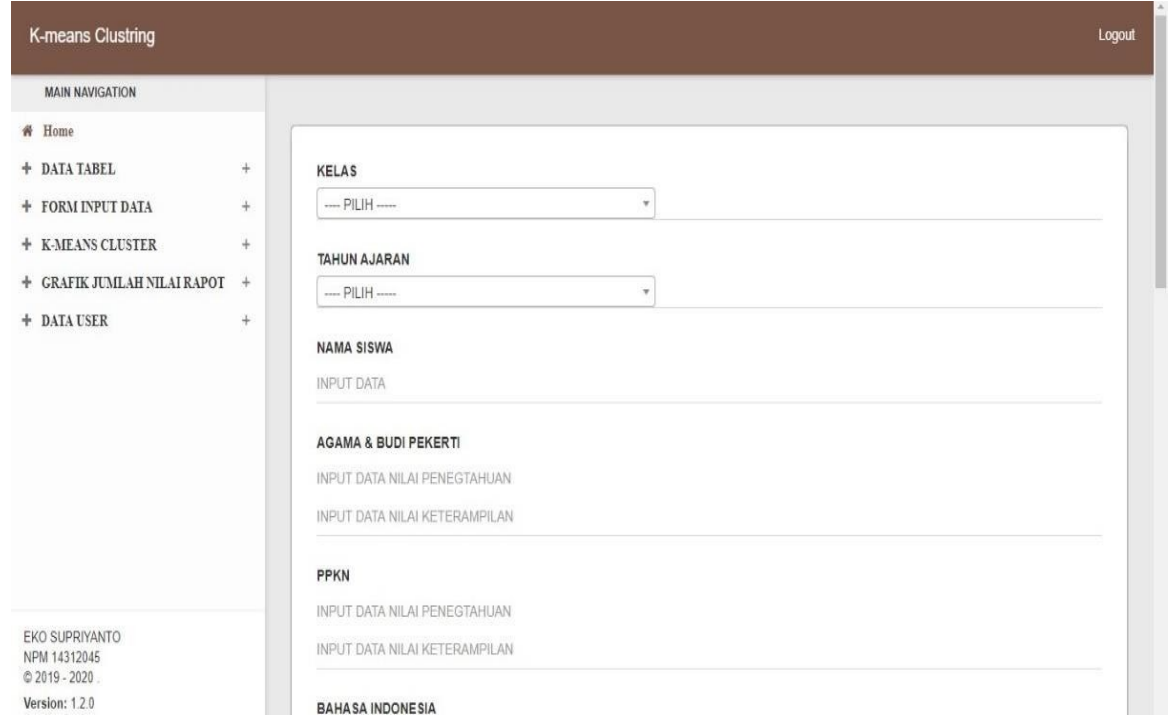

Gambar 5. Input data Nilai Siswa

Implementasi Algoritman K-Means Clustering dimulai dengan penentuan centroid melalui Interface form input centroid titik awal cluster Merupakan design form input interface menetukan centroid awal cluster dengan pembakitan bilangan di tentukan di tetapkan bilangan random maupun bilangan pebakitan max, min. 


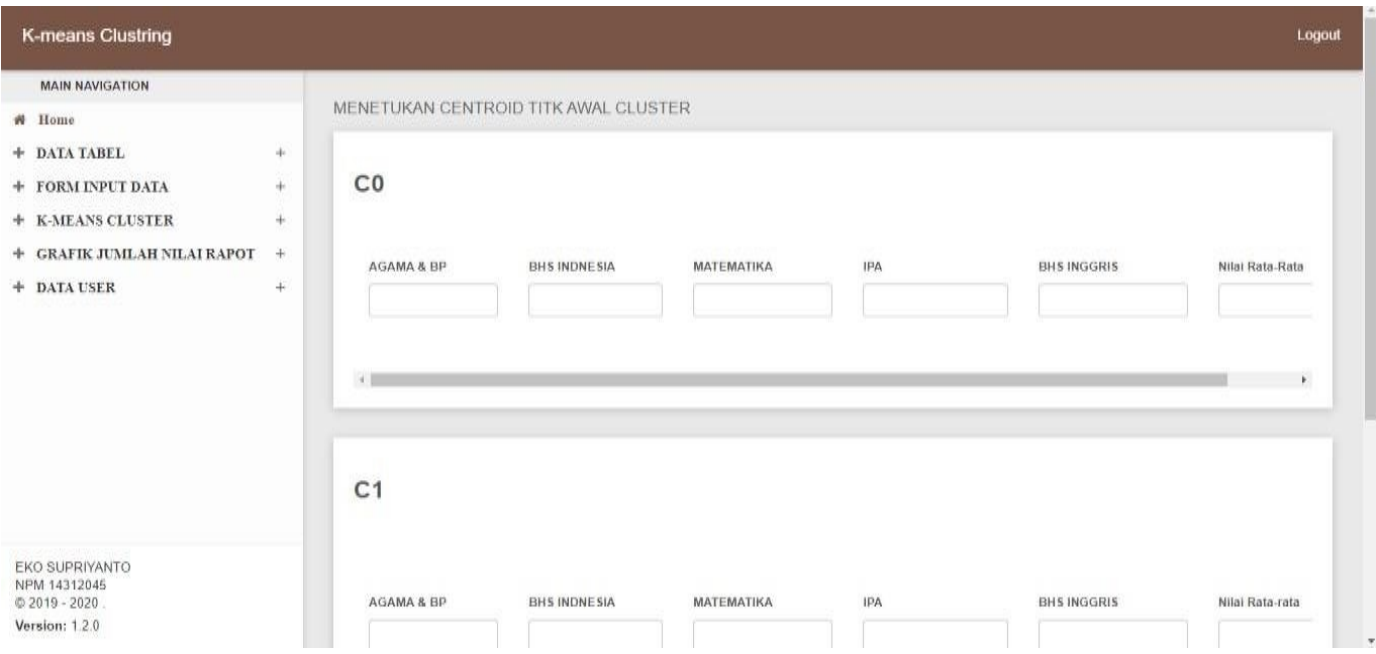

Gambar 6. Penentuan centroid awal

Interface Data Tabel K-Means merupakan interface yang menyajikan data hasil k-means persamaan dalam satu kelompok dan data yang memiliki perbedaan kelompok yang lain sehingga data yang berbeda dalam satu kelompok memiliki tingkat variasi yang kecil. Prinsip utama dari teknik ini adalah menyusun K buah partisi/pusat massa (centroid)/rata-rata (mean) dari sekumpulan data hasil klarifikasi pengelompkan setiap kelas,

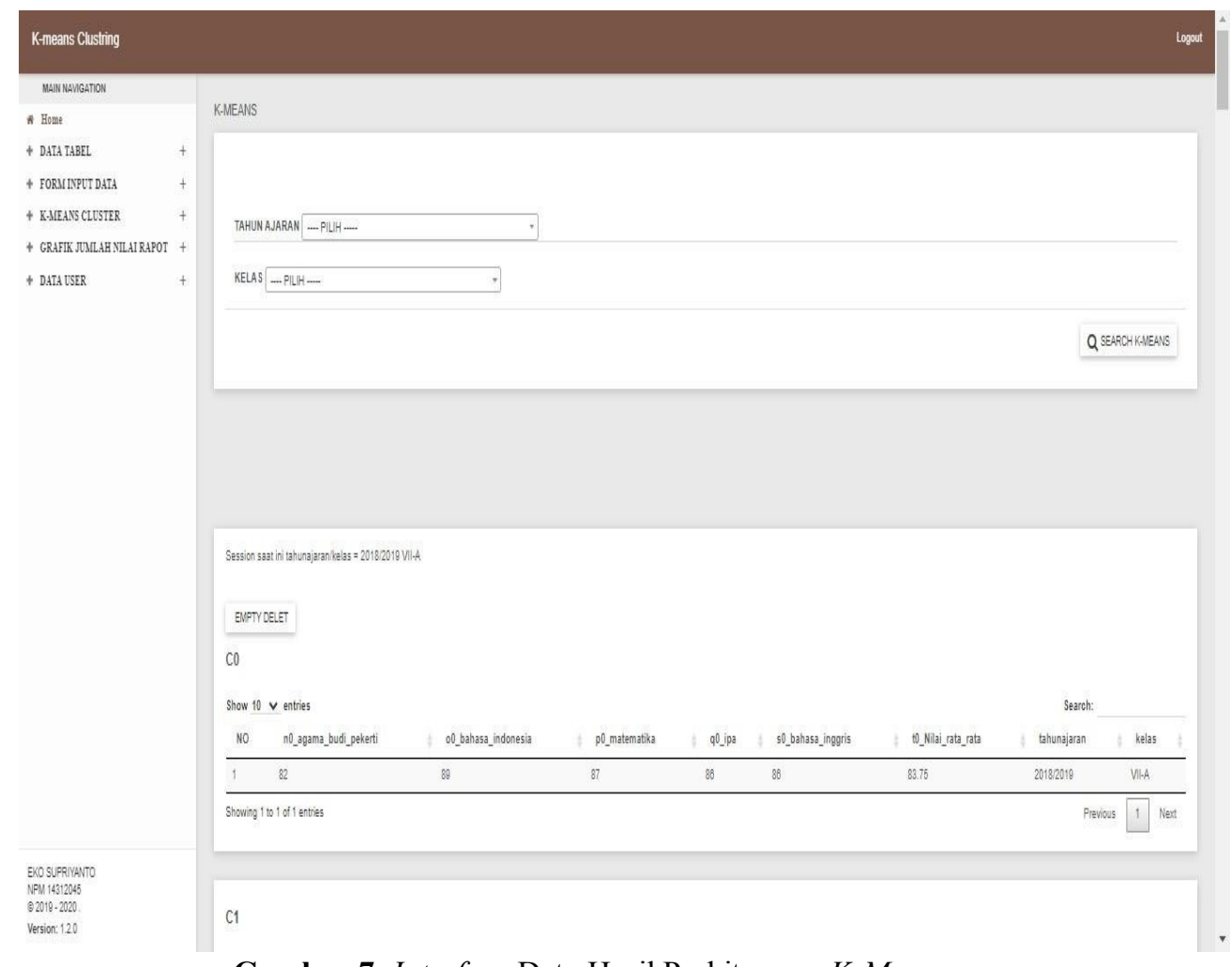

Gambar 7. Interface Data Hasil Perhitungan K-Means 
Interface Grafik Hasil Nilai Rapot merupakan interface jumlah nilai rapot menjadikan objek clustering dan perbandingan nilai rata rata centroid $k$-means clustering ditampilkan dalam gambar berikut.

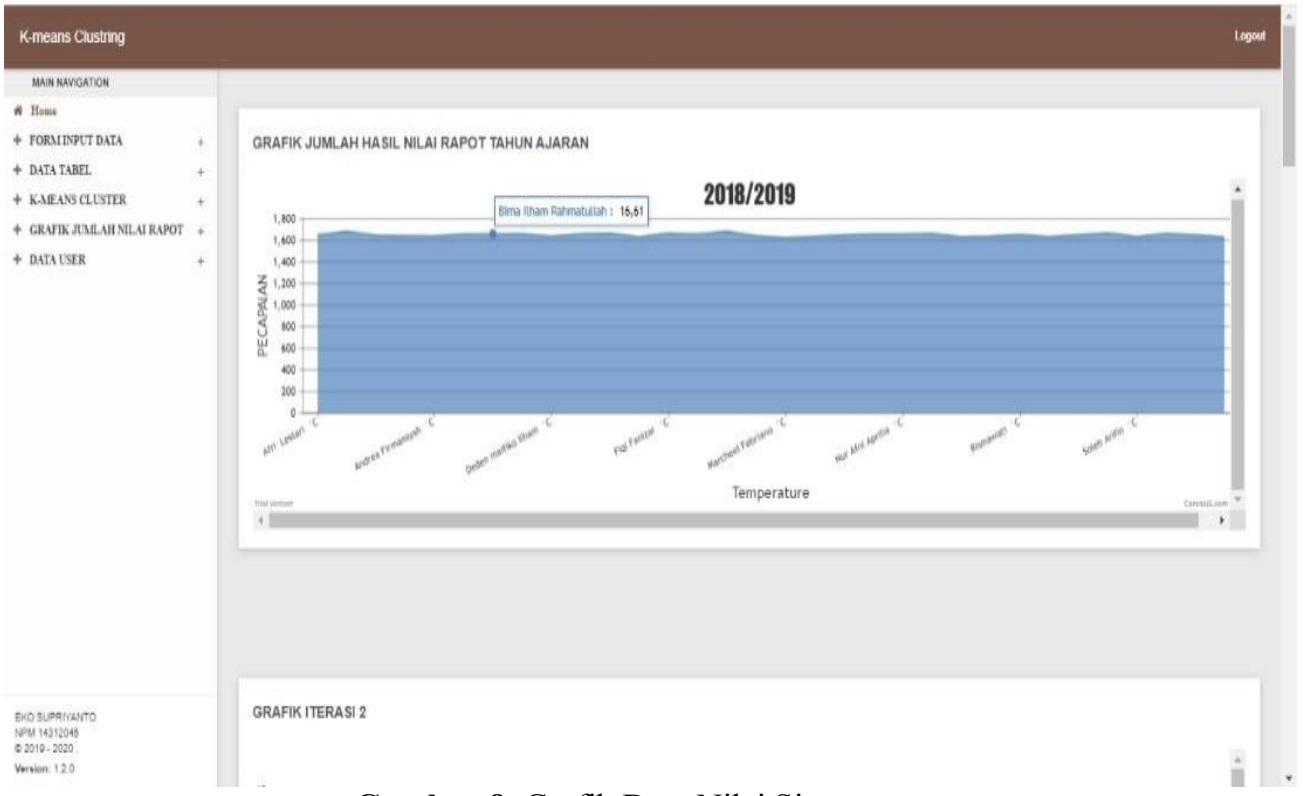

Gambar 8. Grafik Data Nilai Siswa

Implementasi sistem Informasi Klasterisasi Kelas Unggulan yang dikembangkan kemudian diujicoba menggunakan data siswa SMPN 2 Jati Agung Kabupaten Lampung Selatan. Penerapan Algoritma K-Means Clustring yang dihasilkan dari klarifikasi kelas unggulan terbentuk 2 cluster setiap kelas. Hasil cluster pertama kelas A diperoleh anggota 18 dan hasil cluster dua memiliki jumlah anggota 14. Pada kelas $\mathrm{B}$, cluster pertama memiliki anggota 21 dan cluster dua memiliki jumlah anggota 11. Di kelas C, cluster pertama memiliki anggota 18 dan cluster dua memiliki jumlah anggota 15. Pengelompokan di kelas D, cluster pertama memiliki anggota 16 dan cluster dua memiliki jumlah anggota 16. Hasil dari kelas E cluster pertama memiliki anggota 12 dan cluster dua memiliki jumlah anggota 18. Sedangkan pada kelas F, cluster pertama memiliki anggota 11 dan cluster dua memiliki jumlah anggota 21. Dari total data diujikan sebanyak 192. Setiap klasteriasi perputaran dihasilkan Jumlah siswa masuk kelas unggulan sebanyak 96 dan siswa tidak masuk kelas unggulan sebanyak 96.

Hasil perhitungan tersebut dilakukan melalui iterasi didapat dari hasil perhitungan jarak setiap (N objeck) titik pusat centroid cluster awal variable dan aribut nilai siswa untuk menghasilkan nilai (K centroid) partisi/pusat massa (centroid)/rata-rata (mean) centroid 1 maupun centroid 2 dan setiap kelompok memiliki ratarata jarak terdekat. Cluster pengelompokan data tidak memiliki targer variable objeck hanya pembagian hasil kelompok. Didapatkan hingga perputaran ke 6 setiap iterasi hingga pusat cluster tidak bergeser. Iterasi selanjutnya didapat dari hasil titik centroid cluster baru didapatkan dari hasil jumlah keanggotaan jarak data pada centroid. Penentuan centroid (titik pusat cluster) awal pembangkitan bilangan secara Max Penggunaan nilai tertinggi (C0) dan Nilai terendah (C1). Penelitian ini menggunakan 3 iterasi dalam menentukan cluster pengelompokan siswa kelas unggulan. Hal ini sejalan dengan penelitian Faizah Nur, dkk (2017) yang menyatakan bahwa Pusat cluster dengan menerapkan algoritma K-Means Clustering untuk pengelompokan data siswa baru sekolah menengah kejuruan didapat dari beberapa iterasi agar dihasilkan pusat cluster yang optimal.

Pengelompokan data yang dihasilkan oleh aplikasi ini, menurut pendapat pengguna dalam hal ini wakil kepala sekolah bidang Kurikulum di SMPN 2 Jati Agung Kabupaten Lampung Selatan sesuai dengan harapan dan proses berlangsung cepat. Hasil ini juga sesuai dengan penelitian yang dilakukan oleh M. Durairaj et al (2014), yang melakukan Prediksi Kinerja Siswa Menggunakan Algoritma Clustering menunjukkan bahwa algoritma K-Means memberikan prediksi akurat dalam memperkirakan persentase kelulusan dan persentase gagal dari keseluruhan siswa yang muncul dari hasil ujian tertentu. Penggunaan algoritma K-Means untuk aplikasi data mining yang dilakukan melalui proses klasifikasi dan clustering memberikan prediksi hasil yang efektif dan lebih cepat.

Pengujian perangkat lunak dilakukan melalui pengujian blackox untuk pengujian pakar dan pengujian Technology Acceptance Model (TAM) untuk pengujian user. Blackbox (blackbox testing) adalah salah satu metode pengujian perangkat lunak yang berfokus pada sisi fungsionalitas, khususnya pada input dan output aplikasi (apakah sudah sesuai dengan apa yang diharapkan atau belum). Pengujian ini dilakukan hingga 
aplikasi berjalan dengan semestinya dimana seluruh fungsi dan logika dapat berjalan baik. Pengujian dilanjutkan dengan sebaran angket Technology Acceptance Model (TAM) yang digunakan untuk melihat kegunaan sistem yang dikembangkan dapat diimplementasikan atau tidak berdasarkan hasil kuisioner yang dilakukan. Model TAM dapat menjelaskan bahwa persepsi pengguna akan menentukan sikapnya dalam penerimaan penggunaan Teknologi Informasi (TI) berdasarkan 2 faktor, yaitu persepsi kegunaan atau manfaat dan persepsi kemudahan penggunaan (Davis, 1989). Berdasarkan perhitungan angket didapatkan nilai yaitu Kemanfaatan (X1) memilki skor real 393 dari skor ideal 400 dengan persentase 98,25\% (sangat baik), Faktor Kemudahan (X2) memilki skor real 500 dari skor ideal 555 dengan persentase 90,09\% (sangat baik), Penerimaan Sistem (X3) memilki skor real 200 dari skor ideal 205 dengan persentase 97,56\% (sangat baik). Dari hasil persentase sistem informasi $k$-means clustering dapat diterima dan manfaatkan sebagai penentuan siswa kelas unggulan. Hal ini juga sesuai dengan penelitian Syafrizal (2015) bahwa pengujian menggunakan model TAM menggambarkan bahwa penerima penggunaan TI dipengaruhi oleh kemanfaatan (usefulness).

\section{KESIMPULAN}

Berdasarkan hasil pembahasan telah diuraikan, kesimpulan pada tahapan penelitian didapat bahwa implementasi algoritma $k$-means clustering ke dalam sistem informasi klasterisasi memberikan hasil klasifikasi pengelompokan data yang efektif dan proses setiap iterasi perputaran jarak centroid, penetuan titik cluster dibentuk, data siswa sebagai acuan objeck lebih menghemat waktu melakukan klasterisasi kelas unggulan. Penerapan sistem informasi klastrisasi berbasis web ini menghasilkan informasi yang lebih fleksibel dapat diakses kapan saja oleh pengguna yang diberi hak akses untuk memanfaatkan datanya. Penerapan Algoritma KMeans Clustring mendapatkan hasil klarifikasi Kelas unggulan dibutuhkan suatu implementasi sistem informasi terbentuk 2 cluster setiap kelas. Hasil cluster 6 Kelas di SMPN 2 Jati Agung Kabupaten Lampung Selatan, dari total data diujikan sebanyak 192 dihasilkan jumlah siswa masuk kelas unggulan sebanyak 96 dan siswa tidak masuk kelas unggulan sebanyak 96. Tingkat penerimaan pengguna terhadap aplikasi ini 97,56\% (sangat baik) sehingga aplikasi layak untuk digunakan 


\section{REFERENCES}

[1] Widodo. Psikologi Belajar. Jakarta:Rineka Cipta.2013.

[2] Prasetyo, Eko, DATA MINING - Konsep dan Aplikasi Menggunakan MATLAB, Nikodemus, Ed. Yogyakarta, Indonesia: Penerbit ANDI, 2012.

[3] Teguh Wibowo, Penerapan Data Mining Pemilihan Siswa Kelas Unggulan dengan Metode K-Means Clustering di SMP N 02 Tasikmadu, Program Studi Strata I pada Jurusan Informatika Fakultas Komunikasi dan Informatika. 2018.

[4] Himmah, Nofrida Rif'atul. Implementasi Algoritma K-Means Untuk Pengelompokan Siswa Berdasarkan Nilai Akademik (Studi Kasus Mtsn Gresik). Undergraduate Thesis, Universitas Muhammadiyah Gresik. 2019.

[5] Aniek Suryanti Kusuma. Jurnal Sistem Informasi dan Komputer Terapan Indonesia (JSIKTI) Vol.1 (3). Sistem Informasi Akademik Serta Penentuan Kelas Unggulan Dengan Algoritama K-Means di SMP Negeri 3 Ubud, 2 Program Studi Teknik Informatika, STMIK STIKOM, Bali, Indonesia. 2019.

[6] A.S Rosa, dan M.Shalahuddin. Rekayasa Perangkat Lunak Struktur dan. Berorientasi Objek. Bandung : Informatika. 2014.

[7] Fauziah Nur, dkk. InfoTekJar (Jurnal Nasional Informatika dan Teknologi Jaringan), Vol 1 (2), Penerapan Algoritma K-Means Pada Siswa Baru Sekolah Menengah Kejuruan Untuk Clustering Jurusan. 2017. https://jurnal.uisu.ac.id/index.php/infotekjar/article/view/70

[8] M. Durairaj et al, International Journal of Computer Science and Information Technologies, Vol. 5 (4): Educational Data mining for Prediction of Student Performance Using Clustering Algorithms. 2014. https://citeseerx.ist.psu.edu/viewdoc/download?doi=10.1.1.567.8824\&rep=rep1\&type=pdf

[9] D. (1989). Perceived usefulness, perceived ease of use, and user acceptance of information technology, MIS Quarterly 13 (3): 319-340.

[10] Syafrizal, Agusdi dkk. (2015). Penerapan Model Technology Acceptance Model (TAM) untuk Pemahaman Media Pembelajaran Berbasis Multimedia Interaktif. Scientific Journal of Informatics, Vol. 2, No. 1.

http://journal.unnes.ac.id/nju/index.php/sji 